\title{
A huge intramedullary solitary fibrous tumor
}

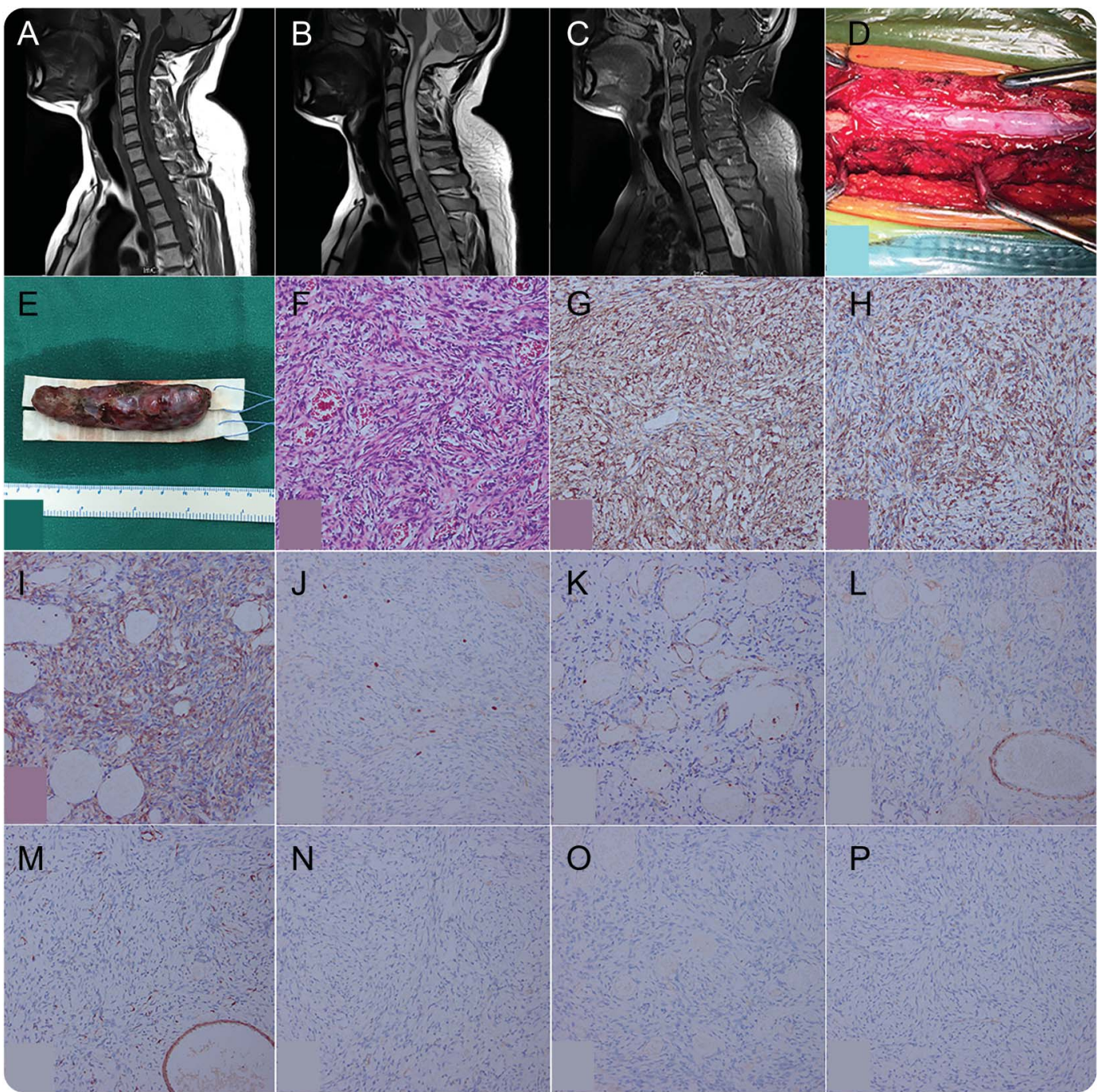

MRI: T1-weighted (A), T2-weighted (B), C (gadolinium contrast); surgery (D); tumor (E); hematoxylin \& eosin (F); immunohistology positive: CD34 (G), BCL-2 (H), CD99 (I), Ki67 (approximately 5\%) (J); immunohistology negative: CD31 (K), desmin (L), smooth muscle actin (SMA) (M), S-100 (N), epithelial membrane antigen (EMA) (O), glial fibrillary acidic protein (GFAP) (P).

A 31-year-old man presented with a 3-year history of progressive weakness and paresthesias of both legs. Spinal MRI revealed a 10-cm intraspinal tumor at T1-T5 with syringomyelia on both ends (figure, A-C). Surgery successfully resected the intramedullary tumor grossly (figure, D and E). Pathology suggested the diagnosis of solitary fibrous tumor (figure, F-P). Intramedullary solitary fibrous tumors are rare, with approximately 17 cases reported and none longer than 2 vertebrae. ${ }^{1}$

Qingfeng Wang, MD, ${ }^{*}$ Xin Hu, MD, ${ }^{*}$ Yiying Wang, MD, Chao You, MD, PhD, Haifeng Chen, $M D$

*These authors contributed equally to this work.

From the Departments of Neurosurgery (Q.W., X.H., C.Y., H.C.) and Pathology (Y.W.), West China Hospital, Sichuan University, China. 
Author contributions: Qingfeng Wang: engaged in clinical care and investigative workup of the patient, study concept and design, acquisition of data, and drafted the manuscript. Xin Hu: revision of manuscript and edit of figure. Yiying Wang: pathologic study. Chao You: study concept and design. Haifeng Chen: in charge of surgery, clinical care and investigative workup of the patient, study concept and design, and revision of manuscript

Acknowledgment: The authors thank the staff (Department of Neurosurgery, West China Hospital) engaged in the surgery and clinical care of the patient.

Study funding: No targeted funding reported.

Disclosure: The authors report no disclosures relevant to the manuscript. Go to Neurology.org for full disclosures.

Correspondence to Dr. Chen: chfbox@163.com

1. Bruder M, Tews D, Mittelbronn M, Capper D, Seifert V, Marquardt G. Intramedullary solitary fibrous tumor: a benign form of hemangiopericytoma? Case report and review of the literature. World Neurosurg 2015;84:189.e7-189.e12.

\section{Minutes Pack a Punch}

\section{Neurology ${ }^{\circledR}$ Podcasts}

- Interviews with top experts on new clinical research in neurology

- Editorial comments on selected articles

- Convenient-listen during your commute, at your desk, or even at the gym

- On demand-it's there when you want it

- Fun and engaging

- New topic each week

- FREE

Listen now at www.aan.com/podcast

\section{How Do YOU Compare? Access New Neurology Compensation and Productivity Report}

The AAN's 2016 Neurology Compensation and Productivity Report and customizable dashboard is now available. Whether you are a physician or practice administrator in a large or small practice setting, the 2016 Neurology Compensation and Productivity Report empowers you to:

- Compare and customize your individual practice-related data with your colleagues at local and national levels

- Determine if you are being compensated fairly relative to your peers

- Use the data in demonstrating your value to payers and to delivering quality patient care

- Discover fair market value based on your subspecialty, region, and practice type

- Create charts and graphs and download them right to your desktop

- Assess patient and practice management principals and implement efficiencies that ultimately can help improve the quality of patient care

Learn more at AAN.com/view/2016NeuroReport. 


\title{
Neurology
}

\author{
A huge intramedullary solitary fibrous tumor \\ Qingfeng Wang, Xin Hu, Yiying Wang, et al. \\ Neurology 2016;87;2171-2172 \\ DOI 10.1212/WNL.0000000000003338
}

This information is current as of November 14, 2016

Updated Information \& Services

References

Subspecialty Collections

Permissions \& Licensing

Reprints including high resolution figures, can be found at: http://n.neurology.org/content/87/20/2171.full

This article cites 1 articles, 0 of which you can access for free at: http://n.neurology.org/content/87/20/2171.full\#ref-list-1

This article, along with others on similar topics, appears in the following collection(s):

All Clinical Neurology

http://n.neurology.org/cgi/collection/all_clinical_neurology

All Imaging

http://n.neurology.org/cgi/collection/all_imaging

All Spinal Cord

http://n.neurology.org/cgi/collection/all_spinal_cord

Autonomic diseases

http://n.neurology.org/cgi/collection/autonomic_diseases

Nerve tumor

http://n.neurology.org/cgi/collection/nerve_tumor

Information about reproducing this article in parts (figures,tables) or in its entirety can be found online at:

http://www.neurology.org/about/about_the_journal\#permissions

Information about ordering reprints can be found online:

http://n.neurology.org/subscribers/advertise

Neurology ${ }^{\circledR}$ is the official journal of the American Academy of Neurology. Published continuously since 1951, it is now a weekly with 48 issues per year. Copyright @ 2016 American Academy of Neurology. All rights reserved. Print ISSN: 0028-3878. Online ISSN: 1526-632X.

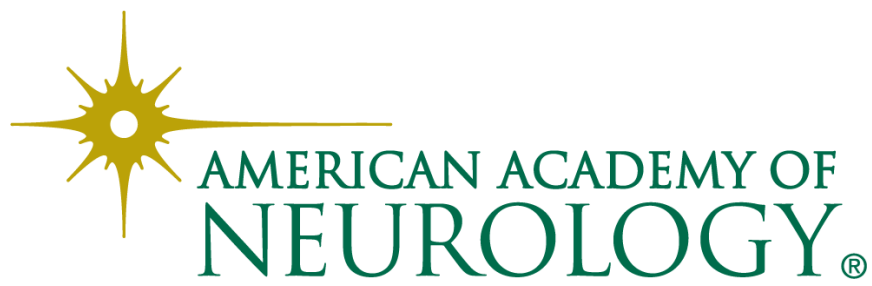

